\title{
Role of Secondary Metabolites and Radical Scavenging Aptitude for Better Adaptability of Mangroves in Varying Salinity of Sundarbans, India
}

\author{
Nirjhar Dasgupta ${ }^{1,2}$, Chandan Sengupta ${ }^{2}$ and Sauren Das ${ }^{1}$
}

${ }^{1}$ Agricultural and Ecological Research Unit, Indian Statistical Institute 203, B.T.Road, Kolkata 700108, India, ${ }^{2}$ Department of Botany, University of Kalyani Kalyani, Nadia, 741235, India

\section{ABSTRACT}

Comparative adaptability in five halophytes (Bruguiera gymnorrhiza, Excoecaria agallocha, Heritiera fomes, Phoenix paludosa and Xylocarpus granatum, of which, $H$. fomes and $X$. granatum presently are stressed in Sundarbans area) were evaluated with respect to occurrence of total phenol, flavonoids, and radical scavenging ability following ABTS [2, 2'-azino-bis (3ethylbenzothiazoline-6-sulphonic acid)], DPPH (1, 1-diphenyl-2picrylhydrazyl) assay and $\mathrm{Fe}_{2}+$ chelating ability.

Amount of total phenol (TP) and flavonoids (TF) were much higher in all taxa grown in Sundarbans than those of mesophytic one. TP and TF were significantly augmented as the substrate salinity increased in $B$. gymnorrhiza, E. agallocha and P. paludosa but disordered in H. fomes and X. granatum, where increment occurred only up to a certain salinity level. Percent of free radical scavenging of extractants by DPPH and ABTS radical perceived significant correlation with salinity in former three but differ in $H$. fomes and X. granatum. Ferrous ion chelating ability also showed the similar trend.

Owing to polyphenols occurrence and ROS scavengers, the present work clearly indicates the better adaptibility of B. gymnorrhiza, E. agallocha and $P$. paludosa in elevated substrate salinity than those of the other two. Lower ROS scavenging ability of $H$. fomes and $X$. granatum also points to their perilous occurrence in elevated saline zones.

Key words: Flavonoids; Phenols; ABTS; $\mathrm{DPPH} ; \mathrm{Fe}_{2}{ }^{+}$chelation; mangroves; Sundarbans.

Correspondence: S. Das Address: Agricultural and Ecological Research Unit, Indian Statistical Institute 203,B.T.Road, Kolkata 700108, India E-mail: sauren@isical.,ac.in DOI: 10.32945/atr3621.2014 
Dasgupta et al.

\section{INTRODUCTION}

Mangroves considered as front line defense of tropical and subtropical coastal and estuarine ecosystem, can efficiently mitigate sea surges (McIvor et al., 2012). But unfortunately, world-wide mangrove area deteriorated from 198,000 $\mathrm{km}^{2}$ to 146,530 $\mathrm{km}^{2}$ since 1980 to 2000 (FAO, 2007) that while a more recent estimation described as $137,760 \mathrm{~km}^{2}$ which is about $0.7 \%$ of the total tropical forest of the world (Giri et al., 2011). These indicate the magnitude of mangrove loss, and calls for serious attention to the significance of mangrove restoration programme. The mangrove formation has immense importance to the coastal inhabitants in both productive (resources of forest products) and protective ways (against cyclonic violence, soil erosion etc.) (Alongi, 2009).

In the Indian subcontinent, Sundarbans mangrove swamp is the world's largest and having richest floral diversity $\left(21^{\circ} 31^{\prime}-22^{\circ} 30^{\prime} \mathrm{N}\right.$ and $88^{\circ} 10^{\prime}-89^{\circ} 51^{\prime}$ E), formed by two major rivers - the Ganga and the Brahmaputra and with their numerous tributaries (Dasgupta et al., 2012). Environmental (tectonic upliftment in north-western part, India and subsidence in the east, Bangladesh) and demographic compulsion (damming on river, urban sewage and industrial wastes expedite siltation in the riverbed) are interrupting the fresh water discharge through river systems, leading to salinity elevation of this zone. The present soil salinity registers between 15 and 27 ppt (Nandy et al., 2007). Haq et al. (1999) estimated that salinity has elevated by $20 \%$ in the Sunderbans since 1990 . Sea level rise, human intervention and reformed ecology are the prime factors of salinity escalation which pose the major threat to the vegetation and triggered rapid annihilation to the forest and even caused extinction to some existing species (Parani et al., 2000). These demographic and environmental adversities have been proved catastrophic for some important plant species of Sundarbans including Aegialitis rotundifolia, Heritiera fomes, Nypa fruticans, Xylocarpus granatum and X. mekongensis (Banerjee, 1999; Upadhaya etal., 2002).

Considerable scientific evidences suggest that under oxidative stress, reactive oxygen species (ROS) such as superoxide, hydroxyl and peroxyl radicals are generated and the stability between anti-oxidation and oxidation is supposed to be a critical concept for maintaining a biological homeostasis (Davies, 2000). Consequently, research on antioxidant principles of plants has been fast-tracked and halophytes 
Role of Secondary Metabolites and Radical Scavenging Aptitude

have been recognized for marked antioxidant potential activities (Tiwari, 2001). Polyphenols are antioxidants, having redox properties, act as reducing agents, hydrogen donators and singlet oxygen quenchers. A number of secondary metabolites were traced from mangroves periodically and have been recognized as pivotal bioactivities towards efficient slat management (Bandarnayeke, 2002; Ravikumar et al., 2010, 2011). Despite of innumerable bioactivities, polyphenols perhaps are mostly attributed to antioxidant property (Sahidi, 2000; Cushnie and Lamb, 2005; Alam, 2011). Some essential phenols and flavonoids were traced from several mangroves (Krishnamoorthy et al., 2011; Yongxin et al.,2012). A variety of antioxidants and their free radical scavenging ability were evaluated from Indian mangroves by Vadlapudi and Naidu (2009).

Polyphenols in plants are well established as a defensive force against detrimental impact of abiotic stress which leads to generate free radicals (Ostrowskaa et al., 2001; Zurina et al., 2010; Lee et al., 2012). The commonly utilized methods of antioxidant activity are ABTS [2, 2'-azinobis (3-ethylbenzothiazoline-6-sulphonic acid)] and DPPH (1, 1-diphenyl2-picrylhydrazyl) assay. Both of them have intense reproducible characteristics under certain assay conditions. $\mathrm{ABTS}^{+}$can be dissolved in aqueous and organic media, in which the antioxidant activity can be measured, due to the hydrophilic and lipophilic nature of the compounds occurring in the plant cells (Arnao, 2000). In contrast, DPPH has been used extensively as a free radical evaluating reducing substances (Cotelle et al., 1996) and for studying the free radical scavenging activities of polyphenol compounds (Duan et al., 2006). DPPH can only be dissolved in organic media, especially in ethanol, and this has a limitation when interpreting the role of hydrophilic antioxidants. Both radicals show similar bi-phase kinetic reactions with many antioxidants. Hydrogen peroxide itself is not very reactive, but it would provide highly reactive species $\mathrm{OH}^{-}$through Fenton reaction (Halliwell and Cross, 1994). Earlier reports suggested that $\mathrm{H}_{2} \mathrm{O}_{2}$ could induce DNA breakage in the intact cell (Imlay, 2003). Thus removal of $\mathrm{H}_{2} \mathrm{O}_{2}$ is decisive for cellular homeostasis. The reducing capacity of a compound may serve as indicator of its potential antioxidant ability (Meir et al., 1995). The antioxidant capacity of compounds has been attributed to various factors such as prevention of chain reaction, chelating metals, reductive capacity and radical scavenging ability (Diplock, 1997; Yildirim et al., 2001).

In view of this, the present work deals with five mangroves taxa of which, two are presently in emaciated occurrence in Sundarbans area, 
taken from five islands with increasing soil salinity. A comparative account of the prevalence of total phenols and flavonoids among the taxa would be indicative regarding the adaptive ability in in-situ condition. The differential magnitude of antioxidative capability among these species has been determined by free radical scavenging result using ABTS and DPPH assay. The antioxidant ability has also been looked into by $\mathrm{Fe}_{2}+$ chelating capacity. All these information might be informative towards the sustainability of the species. For the sake of better appreciation of the process, the same replicas of the taxa are also taken from the mesophytic habitat.

\section{MATERIALS AND METHODS}

Leaves of well matured (about 12-15 years) five taxa were collected in which, two were in distressed condition (Heritiera fomes and Xylocarpus granatum) while the other three were profusely occurring (Bruguiera gymnorrhiza, Excoecaria agallocha and Phoenix paludosa) in the same regime. The collection sites were chosen from naturally occurring in five different islands according to increasing salinity gradient, namely Sajnakhali (22 $\left.08^{\prime} 48^{\prime \prime} \mathrm{N}, 88^{\circ} 50^{\prime} 10^{\prime \prime} \mathrm{E}\right)$, Sudhanyakhali $\left(22^{\circ} 07^{\prime} 35^{\prime \prime} \mathrm{N}, 88^{\circ}\right.$

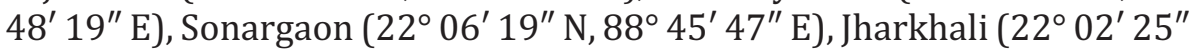

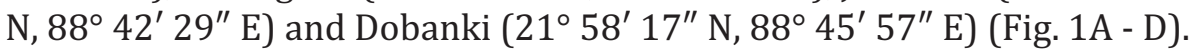
The soil salinities of these places were $11.77 \pm 2.1,12.25 \pm 1.96,12.4 \pm 1.18$, $13.98 \pm 2.29$ and $15.23 \pm 2.16$ ppt respectively (Dasgupta et al. 2012). A controlled mesophytic (at the premises of Indian Statistical Institute, Kolkata where the soil salinity is 2 ppt, (Nandy et al., 2009)) replicas of the studied taxa of well matured up to $12-15$ years old, were also taken for comparative study (Table 1 ).

\section{Preparation of extraction}

Methanolic extracts were prepared by maceration of mature leaves (10gm) with $250 \mathrm{ml}$ of $95 \%$ ethanol, at room temperature for 24 hours and then filtered. The procedure was repeated thrice. The extracts were filtered and centrifuged (4500rpm, $15 \mathrm{~min}$ ). The solvent was evaporated on rotary evaporator (Neocool Circulator, CF 300, Yamato). The concentrated methanolic leaf extracts were kept frozen $\left(-20^{\circ} \mathrm{C}\right)$ until further use (Huda-Faujan et al., 2009). Leave samples were collected from three individuals of each species from each site. 

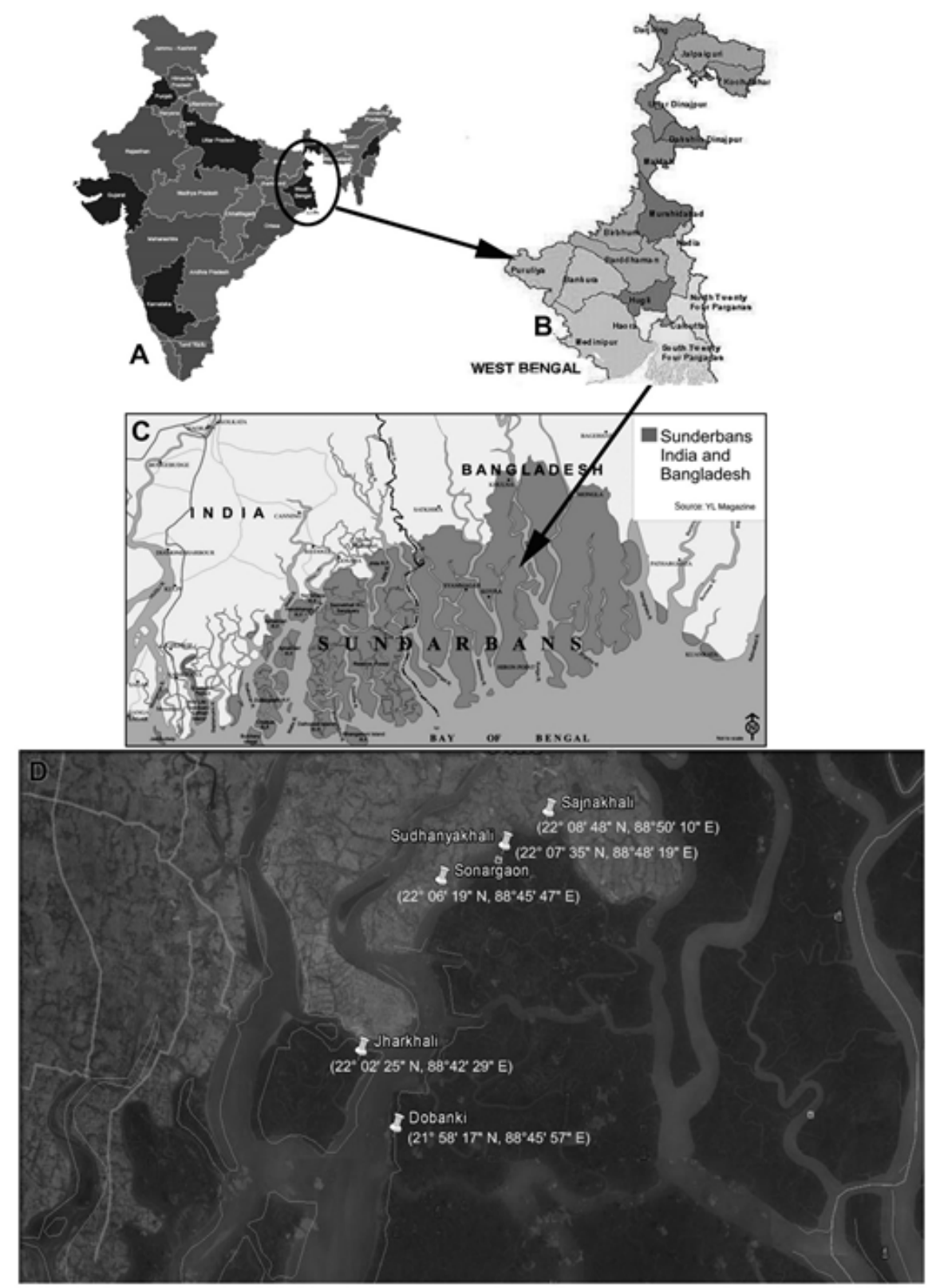

Fig. 1.

Fig. 1. A-D. Maps of location areas. A. Map of India; B. Map of West Bengal; C. Map of lower Bengal basin, where the Sundarbans mangrove forest included; D. Expanded map of study site of the islands of Sundarbans, indicating the geographic position. 
Table 1. Location and soil salinity of the collecting sites.

\begin{tabular}{lccc}
\hline \multicolumn{1}{c}{ Name of Islands } & Lat/Long values & Salinity (ppt) & Named as \\
\hline ISI Garden & $22^{\circ} 38^{\prime} 43^{\prime \prime} \mathrm{N}$, & $2.0 \pm 1.21$ & Site 1 \\
(mesophytic) & $88^{\circ} 22^{\prime} 33^{\prime \prime} \mathrm{E}$ & & \\
Sajnakhali & $22^{\circ} 08^{\prime} 48^{\prime \prime} \mathrm{N}$, & $11.77 \pm 2.1$ & Site 2 \\
(Sundarbans) & $88^{\circ} 50^{\prime} 10^{\prime \prime} \mathrm{E}$ & & \\
Sudhanyakhali & $22^{\circ} 07^{\prime} 35^{\prime \prime} \mathrm{N}$, & $12.25 \pm 1.96$ & Site 3 \\
(Sundarbans) & $88^{\circ} 48^{\prime} 19^{\prime \prime} \mathrm{E}$ & & \\
Sonargaon & $22^{\circ} 06^{\prime} 19^{\prime \prime} \mathrm{N}$, & $12.4 \pm 1.18$ & Site 4 \\
(Sundarbans) & $88^{\circ} 45^{\prime} 47^{\prime \prime} \mathrm{E}$ & & \\
Jharkhali & $22^{\circ} 02^{\prime} 25^{\prime \prime} \mathrm{N}$, & $13.98 \pm 2.29$ & Site 5 \\
(Sundarbans) & $88^{\circ} 42^{\prime} 29^{\prime \prime} \mathrm{E}$ & & \\
Dobanki & $21^{\circ} 58^{\prime} 17^{\prime \prime} \mathrm{N}$, & $15.23 \pm 2.16$ & Site 6 \\
(Subdarbans) & $88^{\circ} 45^{\prime} 57^{\prime \prime} \mathrm{E}$ & & \\
\hline
\end{tabular}

\section{Determination of Total Phenol}

Total phenol contents in the extracts were determined following modified Folin-Ciocalteu method (Singleton and Rossi, 1965). Aliquots (0.05-0.3 mg ml $\left.{ }^{1}\right)$ of the extractants were prepared for all the samples. To $0.1 \mathrm{ml}$ of the methanolic solution of the extractants, $2 \mathrm{ml}$ of Folin-Ciocalteu reagent (previously diluted with water at $1: 10 \mathrm{v} / \mathrm{v}$ ) and $1.6 \mathrm{ml}(7.5 \%)$ of Sodium carbonate $\left(\mathrm{Na}_{2} \mathrm{CO}_{3}\right)$ were added. The mixture was allowed to react at room temperature for $30 \mathrm{~min}$ for colour development. Spectrophotometric absorbance (He $\lambda$ ios $\gamma$, Thermo Electron Corporation) was measured at $765 \mathrm{~nm}$. Gallic acid was used as a positive control in the same concentrations. The total phenolic content was expressed as gallic acid equivalents (GAE) in $\mathrm{mg} \mathrm{g}^{-1}$ of dry material based on the calibration curve, where $\mathrm{X}$ was the absorbance and $\mathrm{Y}$ was the gallic acid equivalent $\left(\mathrm{mg} \mathrm{g}^{-1}\right)$. Each experiment was carried out in triplicates.

\section{Determination of Total Flavonoids}

Estimation of total flavonoids in the plant extracts was carried out following Jia et al. (1999). Aliquots (0.2-1.2 $\left.\mathrm{mg} \mathrm{ml}^{-1}\right)$ of the extractants were prepared for all the samples. To $0.1 \mathrm{ml}$ of methanolic solution of the extractants, $0.3 \mathrm{ml}$ of $5 \%$ Sodium nitrite $\left(\mathrm{NaNO}_{2}\right)$ was added and mixed well. The mixture was kept at $25^{\circ} \mathrm{C}$ temperature for $5 \mathrm{~min}$. Then, $0.3 \mathrm{ml}$ of $10 \%$ Aluminum chloride $\left(\mathrm{AlCl}_{3}\right)$ was added. The tubes were then allowed to stand at room temperature for $5 \mathrm{~min}$. After which, $1 \mathrm{mM}$ Sodium hydroxide $(\mathrm{NaOH})$ solution was added and the absorbance of the solution was measured at $510 \mathrm{~nm}$. Quercetin was used in the same concentration as a 
Role of Secondary Metabolites and Radical Scavenging Aptitude

positive control. Total flavonoid content was calculated as quercetin equivalent ( $\mathrm{mg} \mathrm{g}^{-1}$ ) using the following the calibration curve, where $\mathrm{X}$ was the absorbance and $\mathrm{Y}$ was the quercetin equivalent ( $\mathrm{QE} \mathrm{mg} \mathrm{g}^{-1}$ ). Each experiment was carried out in triplicates.

\section{ABTS+ scavenging assay}

To determine ABTS radical scavenging assay, the method of Re et al. (1997) was adopted. The working solution was prepared by mixing two stock solutions $7 \mathrm{mM}$ ABTS solution and $2.4 \mathrm{mM}$ potassium per-sulfate solution, in equal quantities and allowing them to react for 12 hours at room temperature in the dark. This solution was diluted 60 times while working. Fresh ABTS solution was prepared for each assay. Plant extract $(0.1 \mathrm{ml})$ in methanol containing $0.005-0.03 \mathrm{mg} \mathrm{ml}^{-1}$ conc. of the extract were allowed to react with $3 \mathrm{ml}$ of the ABTS solution and the absorbency was taken at $734 \mathrm{~nm}$ after $7 \mathrm{~min}$. Butylated Hydroxy Toluene (BHT) in the same concentration as the sample was used as positive control. Each experimental data was taken in triplicates. The ABTS scavenging capacity of the extract was calculated as:

ABTS radical scavenging activity $(\%)=\left\{\left(A_{c}-A_{t}\right) / A_{c}\right\} \times 100$

Where $A_{c}$ is the absorbance of the blank reaction and $A_{t}$ is the absorbance in presence of the sample of the extracts. Each experiment was carried out in triplicates.

\section{DPPH quenching assay}

The free radical scavenging activity of different plant extracts was determined using the stable radical DPPH (1, 1-diphenyl-2picrylhydrazyl) following Ribeiro et al. (2002). Freshly prepared DPPH solution ( $25 \mathrm{mg} \mathrm{L}^{-1}$ ) in methanol was prepared and $3.9 \mathrm{ml}$ from this was mixed with $0.1 \mathrm{ml}$ of extract in methanol containing $0.05-0.3 \mathrm{mg} \mathrm{ml}^{-1}$ conc. of the extract. The absorbance was measured at $517 \mathrm{~nm}$ after 30 minutes. Butylated Hydroxy Toluene (BHT) in the same concentration as the sample was used as positive control. Each experimental data was taken in triplicates. The capability to scavenge the DPPH radical was calculated using the following equation: 
DPPH radical scavenging activity $(\%)=\left\{\frac{A c-A t}{A c}\right\} \times 100$

Where $A_{c}$ is the absorbance of the blank reaction and $A_{t}$ is the absorbance in presence of the sample of the extracts. Each experiment was carried out in triplicates.

\section{$\mathrm{Fe}_{2}{ }^{+}$chelating study}

The chelating activity of the extracts for ferrous ion was measured following Haro-Vicente et al. (2006) with minor adjustments. The reaction was carried out in HEPES buffer $(20 \mathrm{mM}, \mathrm{pH} 7.2)$. Various concentrations of the plant extracts $\left(0-300 \mathrm{mg} \mathrm{ml}^{-1}\right)$ were added to $12.5 \mathrm{mM}$ ferrous sulfate solution and the reaction was initiated by the addition of ferrozine (75 mM). The mixture was shaken vigorously and incubated for $20 \mathrm{~min}$ at room temperature. The absorbance is measured at $562 \mathrm{~nm}$. Three repeats were done for each test. EDTA was used as a positive control.

$$
\mathrm{Fe}^{2+} \text { Chelation ability }(\%)=\left\{\frac{A c-A t}{A c}\right\} \times 100
$$

Where $A_{c}$ is the absorbance of the blank reaction and $A_{t}$ is the absorbance in presence of the sample of the extracts.

In all scavenging/chelating ability are expressed in terms of $\mathrm{IC}_{50}$. It is defined as the concentration of the plant extract that's needed to scavenge/chelate $50 \%$ of the scavengers/chelating ions present were calculated by the following equation:

$$
\mathrm{IC}_{50}=\left\{\frac{\text { Percent Inhibition }}{\text { Concentration of the sample }}\right\} \times 50
$$

Pearson coefficient, (two-tailed bivariate correlation coefficient) was estimated for each parameter such as amount of incidence of total phenols and flavonoids, percent inhibition of free radical scavenging by DPPH and ABTS assay and percent ability to $\mathrm{Fe}_{2}{ }^{+}$chelation in respect to salinity increment were considered. The correlations among the said parameters were derived using SPSS (version 12.0) software.

\section{RESULTS AND DISCUSSION}

Estimated total phenol (TP) in all studied plants was much higher in plants grown in Sundarbans than those of the mesophytic individuals. In mesophytic 
Role of Secondary Metabolites and Radical Scavenging Aptitude

plants, highest TP was observed in P. paludosa (35.59 GAE $\mathrm{mg} \mathrm{g}^{-1}$ ) and in other taxa, ranged within $8.68-12.65 \mathrm{GAE} \mathrm{mg} \mathrm{g}^{-1}$. The amount increased consistently along the increasing soil salinity in B. gymnorrhiza, E. agallocha and $P$. paludosa but this trend was disrupted in $H$. fomes and $X$. granatum. Amount of total phenol increased up to site 4 in $H$. fomes $\left(32.54 \mathrm{mg} \mathrm{g}^{-1}\right)$ and up to site 3 in $X$. granatum (38.48 $\mathrm{mg} \mathrm{g}^{-1}$ ), beyond which it decreased. TP increment in $H$. fomes was nominal from site 3 to site 4 (31.54 and $32.45 \mathrm{mg} \mathrm{g}^{-1}$ respectively) and in $X$. granatum TP increment over mesophytic condition was up to site 3 and it went down in site 4, 5 and 6 (35.59, 31.56 and $31.48 \mathrm{mg} \mathrm{g}^{-1}$ respectively) (Fig.2A).

The incidence of Total Flavonoids (TF) was expressed in Quercetin equivalent. In B. gymnorrhiza, E. agallocha and P. paludosa, TF was recorded as maximum from site $6\left(46.42 \mathrm{mg} \mathrm{g}^{-1}\right.$ in E. agallocha, $43.55 \mathrm{mg} \mathrm{g}^{-1}$ in $B$. gymnorrhiza and $39.54 \mathrm{mg} \mathrm{g}^{-1}$ in P. paludosa) over the control plants and the increment was consistent as the salinity rise from site 1 to site 6 (Fig. 2B). But in other two taxa, these trends were not found with the raised soil salinity. In $H$. fomes, the increment of TF recorded over the control environment was up to site 3 , beyond this it gradually decreased (highest in site $3,26.72 \mathrm{mg} \mathrm{g}^{-1}$ ) in site 4, 5 and 6 (Fig. 2B). The highest TF occurrence in $X$. granatum was recorded from sites 3 and 4 over control plants (almost same in the two sites, 16.54 and 16.59 $\left.\mathrm{mg} \mathrm{g} \mathrm{mg} \mathrm{g}^{-1}\right)$. It gradually came down with the soil salinity increase in site 5 and

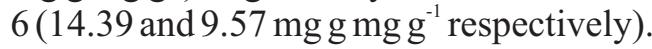

To determine the free radical scavenging as an index of antioxidant ability of the investigated taxa, DPPH assay was performed. In this experiment, the percent inhibitions were increased as the substrate salinity increased in B. gymnorrhiza, E. agallocha and P. paludosa over the mesophytic individuals. But in $H$. fomes and $X$. granatum, the percent inhibition decreased beyond the site 4 (Fig. 2C). IC $_{50}$ values were calculated in all the cases which reflected the usual reverse diagrams (Fig. 2D). The highest percent inhibition was recorded in E. agallocha (17. 8) grown in highest substrate salinity level. The magnitude of inhibition in $H$. fomes and $X$ granatum observed in site 4 (6.248 and 4.865 respectively), where in other three taxa in the same salinity level were 15.23 (B. gymnorrhiza), 9.87 (E. agallocha) and 8.64 (P. paludosa) and beyond this, the percent inhibition increased further for these three taxa as the salinity increased.

Antioxidant ability was further studied in all taxa with ABTS+ radical scavenging efficiency along the substrate salinity gradients. In this assay, similar results were obtained as DPPH assay in B. gymnorrhiza, E. agallocha and $P$. paludosa, the percent inhibition of cation radical were enhanced as the salinity level hiked. But this trend was discontinues at site 4 in $H$. fomes and at site 5 in X. granatum, where beyond these sites along the salinity 
gradient, the percent inhibition dwindled. Highest inhibition occurred at site 6 as 34.29 (E. agallocha), 31.95 (P. paludosa) and 25.26 (B. gymnorrhiza). In the same site $H$. fomes and X. granatum showed 18.84 and 23.26 percent of inhibition (Fig. 2E). Incidence of $50 \%$ inhibition $\left(\mathrm{IC}_{50}\right)$ depicted reverse of percent scavenging (Fig. 2F).

The $\mathrm{Fe}_{2}+$ chelating assay determines the antioxidants confined in the samples as reductants in colorimetric reaction, which is redox-linked and the results reveal the antioxidants reducing power. A higher absorbance tallies to a higher ferric reducing ability and $\mathrm{IC}_{50}$ values were calculated, which denotes the concentration of samples required for scavenging $50 \%$ of the free radicals. The present experiment publicized that in $B$. gymnorrhiza, E. agallocha and P. paludosa the reducing ability were distinct along with the increasing salinity, though in P. paludosa the increment was not as high as the other two. The percent inhibitions were noted from these three taxa maximized in site 6 (35.86 in B. gymnorrhiza, 36.85 in E. agallocha and 21.98 in P. paludosa). But H. fomes touched peak in site 2 (18.39), after that the value reduced as salinity increased and in last two sites, remain more or less the same. X. granatum exhibited its highest ferric reducing ability at site 2 (17.66), it reduced at next 4 sites with increased salinities. The graphical representation of percent inhibition was depicted in Fig. $2 \mathrm{G}$ and the bar diagram of $\mathrm{IC}_{50}$ represented the reverse of the percent inhibition diagram (Fig. $2 \mathrm{H}$ ).

A two-tailed bivariate correlation coefficient (Pearson coefficient) was calculated (using SPSS 12.0 softwere) for each parameter in respect to salinity (Table 2). In this part, amount of increment of total phenols and flavonoids, percent inhibition of free radical scavenging by DPPH and ABTS assay and percent ability to $\mathrm{Fe}_{2}{ }^{+}$chelation in respect to salinity hike were considered. The analysis revealed that all studied taxa showed fairly positive correlation with the salinity, the correlation values were significant $(\mathrm{p} \leq 0.01)$ in B. gymnorrhiza, E. agallocha and P. paludosa $\left(\mathrm{r}^{2}=0.974,0.944\right.$ and 0.949 respectively), but in case of $H$. fomes and $X$. granatum, the correlation values were 0.822 and $0.860(\mathrm{p} \leq 0.05)$. In case of flavonoids, significant correlation only exist in former three species (0.889, $\mathrm{p} \leq 0.05$ in B. gymnorrhiza; 0.952, $\mathrm{p} \leq 0.01$ in E. agallocha and 0.904, $\mathrm{p} \leq 0.05$ in P. paludosa), other two have no significant relationships.

Percent inhibition of free radicals by DPPH and ABTS also exhibited the significant relationship with salinity in case of former three species. These three species showed high significant correlation in ferric ion chelation ability with salinity, whereas rest two did not reveal significant correlation 
Role of Secondary Metabolites and Radical Scavenging Aptitude

values. Percent inhibition of DPPH radical is well correlated with the incidence of TP and TF in all cases at significant level $\mathrm{p} \leq 0.01$, except $H$. fomes ( $\mathrm{p} \leq 0.05)$. In X. granatum, DPPH and flavonoids occurrence was not significantly correlated. ABTS assay of free radical scavenging and occurrence of TP and TF also produced the same trend for X. granatum. Ferric ion chelating ability in respect to TP revealed maximum correlation in B. gymnorrhiza, E. agallocha, X. granatum and P. paludosa $(\mathrm{p} \leq 0.01)$, but $H$. fomes showed least. In case of TF, except $H$. fomes and $X$. granatum, all other studied taxa were significantly correlated.

Table 2. Correlations among salinity and other investigated factors for each plant

\begin{tabular}{|c|c|c|c|c|c|c|}
\hline \multirow{6}{*}{ 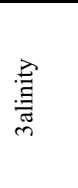 } & B. gymnorrhiza & E. agallocha & H. fomes & P. paludosa & X. granatum & Treatments \\
\hline & $0.974 * *$ & $0.944 * *$ & $0.822 *$ & $0.949 * *$ & $0.860^{*}$ & Phenols \\
\hline & $0.889^{*}$ & $0.952 * *$ & 0.329 & $0.904^{*}$ & 0.294 & Flavonoids \\
\hline & $0.928 * *$ & $0.856^{*}$ & 0.582 & $0.981 * *$ & 0.414 & ABTS \\
\hline & $0.946^{* *}$ & $0.890^{*}$ & 0.646 & $0.884 *$ & 0.734 & DPPH \\
\hline & $0.966^{* *}$ & $0.962 * *$ & 0.316 & $0.919 * *$ & 0.738 & $\mathrm{Fe}_{2}^{+}$ \\
\hline \multirow[t]{2}{*}{ DPPH } & $0.831^{*}$ & $0.968 * *$ & $0.892 *$ & $0.922 * *$ & $0.956^{* *}$ & Phenols \\
\hline & $0.944 * *$ & $0.934 * *$ & $0.864^{*}$ & $0.963 * *$ & 0.596 & Flavonoids \\
\hline \multirow[t]{2}{*}{ ABTS } & $0.993 * *$ & $0.978^{* *}$ & $0.868^{*}$ & $0.981 * *$ & $0.870^{*}$ & Phenols \\
\hline & $0.971 * *$ & $0.942 * *$ & $0.865^{*}$ & $0.959 * *$ & 0.544 & Flavonoids \\
\hline \multirow[t]{2}{*}{$\mathrm{Fe}_{2}^{+}$} & $0.989 * *$ & $0.963 * *$ & 0.733 & $0.921 * *$ & $0.975 * *$ & Phenols \\
\hline & $0.963 * *$ & $0.986^{* *}$ & 0.736 & $0.852^{*}$ & 0.575 & Flavonoids \\
\hline
\end{tabular}

** Correlation is significant at the 0.01 level (2-tailed).

* Correlation is significant at the 0.05 level (2-tailed)..

The present work demonstrated the amount of total phenols, flavonoids and free radical scavenging ability of five mangroves, among which three are abundantly growing in Sundarbans region and while the other two exhibited scarce occurrence from five different islands of varying substrate salinity. The same plants were taken from mesophytic conditions, considered as control experiment. Incidence of total phenol in all studied taxa has a strong positive association with the salinity though this affinity was less significant in two taxa, $H$. fomes and $X$. granatum. TP increment was observed up to a certain limit of salinity, beyond which it decreased. In mangrove species, normally total phenols are copious components, which avert damage from herbivores (Feller et al., 1999; Hernes et al., 2001), but basically their major role in plant system is involve in antioxidative radical scavenging (Banerjee et al., 2008; Rahim et al., 2008; Zhang etal., 2010).

Phenolic compounds are commonly found in plants and have been reported towards several biological activities including a strong antioxidant activity (Duh et al., 1999; Chandini et al., 2008). The 


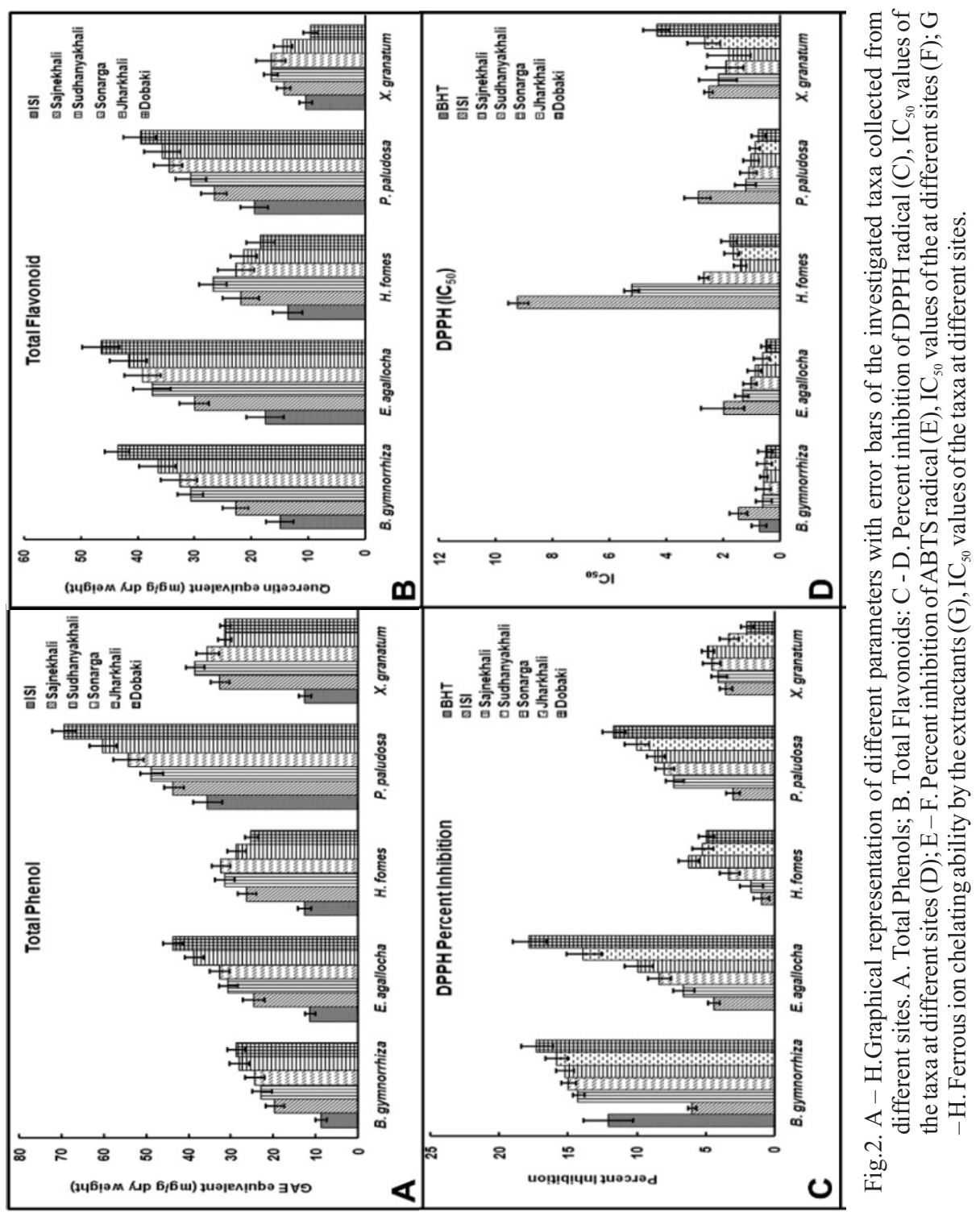


Role of Secondary Metabolites and Radical Scavenging Aptitude

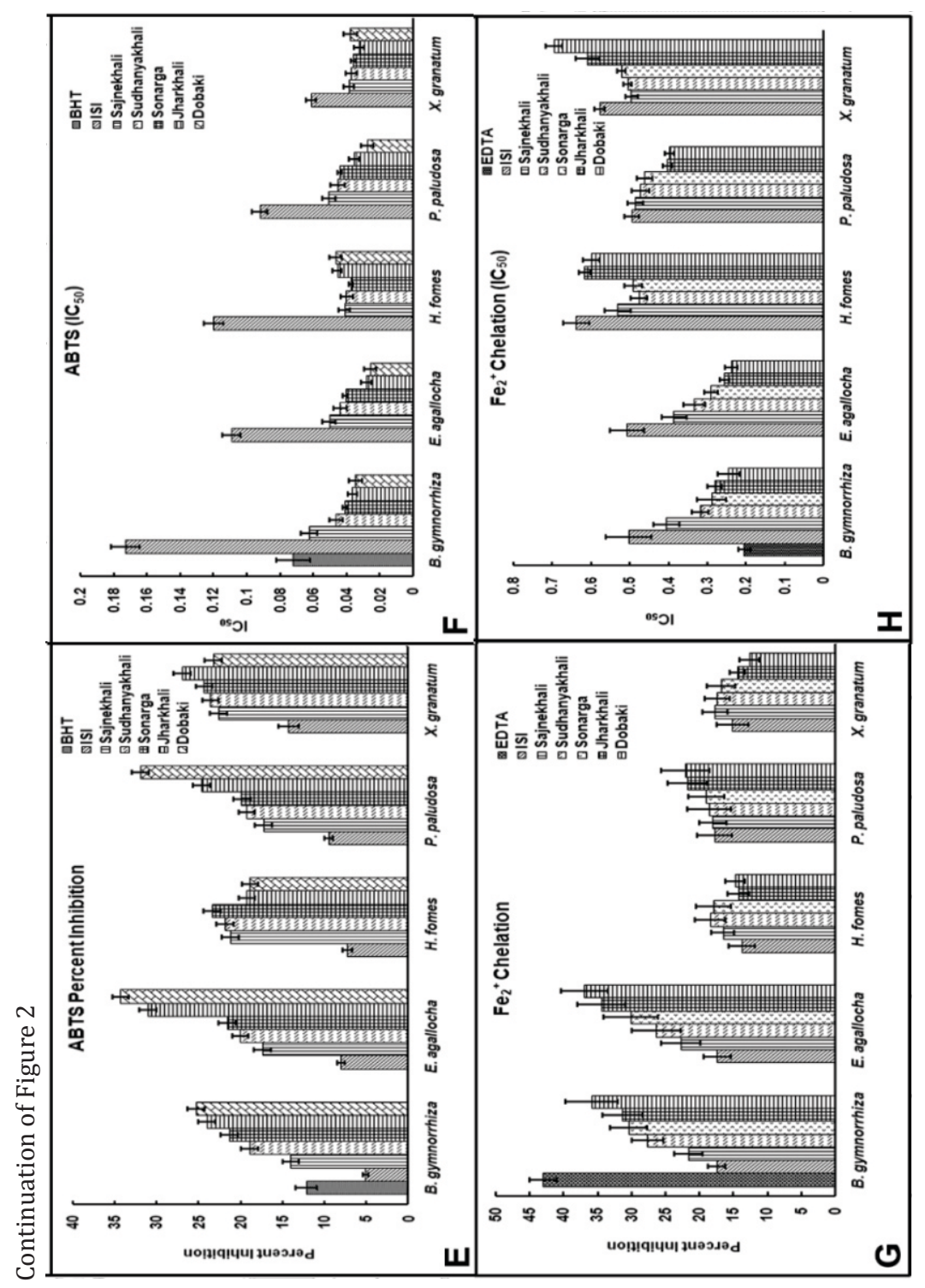


antioxidant capacity of phenolic extracts is very often attributed to their radical scavenging ability mediated by hydroxyl groups (Hatano et al., 1989).

The flavonoids have been recognized as important components in Plant leaves. Metcalfe (1987) opined that $20 \%$ of the carbon that have been fixed by photosynthesis have channelized through phenylpropanoid pathway leading to generate most of the naturally occurring polyphenols. It is established that plant polyphenols and, especially, flavonoids are the most important defensive antioxidants in stressful condition (Agati and Tattini, 2010; Pollastri and Tattini, 2011; Brunetti et al., 2013). Agati et al. (2012) commented that flavonoids effectively absorb the active solar wavelengths (UV-B and UV-A), hinder the generation of reactive oxygen species (ROS) and scavenge ROS once they are formed. With several endogenous antioxidants, flavonoids play a role in optimum protection from oxidative stress caused by the increased level of ROS. Antioxidative mechanism of flavonoids includes suppressing ROS formation (by inhibition of enzymes or chelating trace elements involving ROS generation), direct ROS scavenging and up-regulating or protecting antioxidant defenses (Middleton and Kandaswami, 1993; Pietta, 2000). In the present observation, incidence of flavonoids in the leaves extracts from the three species (B. gymnorrhiza, E. agallocha and P. paludosa) were high than those of the two (H. fomes and X. granatum). As the substrate salinity elevated in different sites, the flavonoids occurrence also increased in the former three species indicating their better suitability in increased salinity, whereas, the latter two species show different trend. The flavonoids increment over the control plants was continued up to a certain limit of substrate salinity in these two species, beyond that, its diminution designating their weaker adaptability in high saline environment. Scientific suggestion revealed that, under abiotic stress, excess generation of ROS, such as superoxide, hydroxyl and peroxyl radicals occurs and the balance between antioxidation and oxidation is supposed to be a critical perception for keeping a well biological system (Davis, 2000).

It has been demonstrated that salt stress is expected to encourage the generation of ROS in plants (M'Rahs et al., 2007). Plants respond to salt stress by decreasing stomatal conductance to avoid excessive water loss. This in turn decreases the internal $\mathrm{CO}_{2}$ concentrations and slows down the reduction of $\mathrm{CO}_{2}$ by Calvin cycle. This response leads to depletion of the oxidized $\mathrm{NADP}^{+}$which acts as a final acceptor of electrons in PSI, and alternatively increases the leakage of electrons to $\mathrm{O}_{2}$ forming $\mathrm{O}^{-2}$ (Hsu and 
Role of Secondary Metabolites and Radical Scavenging Aptitude

Kao, 2003). Furthermore, $\mathrm{Na}^{+} / \mathrm{Cl}^{-}$toxicity resulting from salt stress could disrupt the photosynthetic electron transport and provoke electron leakage to $\mathrm{O}_{2}$. Nychas et al. (2003) claimed that polyphenols are antioxidants (having redox properties), potentially act as reducing agents, hydrogen donators and singlet oxygen quenchers. Jithesh et al. (2006) commented that in increased salinity, physiological water deficit causing abscisic acid regulated stomatal closure in leaves leading to limited $\mathrm{CO}_{2}$ availability, ultimately over reduction of electron transport chain, and finally generation of ROS. In this work, free radical scavenging ability also evaluated by percent reduction of leaves extracts by DPPH, ABTS and chelation of ferric ion and were well correlated with the increasing soil salinity, at least in those species, which are predominant in in situ condition (B. gymnorrhiza, E. agallocha and P. paludosa), but these trends were interrupted in $H$. fomes and $X$. granatum - the taxa which are now precarious in nature. Mangroves are inhabitants in extreme inimical microclimate with high salinity, irradiation and depleted nutrition with rapid tidal fluctuation (Naskar and Guha Bakshi, 1995). These leading to production of excess ROS and to nullify the deleterious consequences, amount of antioxidative enzymes and secondary metabolites are also sufficiently elevated. Scientific evidences proved that mangroves are generously endowed with polyphenol compounds (phenols and flavonoids), which help to cope with the oxidative stress by exploitation of potent antioxidant (Banerjee et. al., 2008; Chandini et al., 2008).

Beside the genetic regulator, a biochemical mechanism, which are regulated in a way that allows halophytes to nurture and flourish in salt stress environment contributing them a definite advantage over other glycophytes. Inductions of antioxidants (enzymes and secondary metabolites) were shown to protect halophytes against ROS, leading toprevention of lipid peroxidation during salt stress (Hasegawa et al., 2000a, b; Jithesh et al., 2006). This confirms that these antioxidants are indispensable towards adaptive defense mechanism against salt stress in halophytes. In the present work, it publicized that the salinity plays a major role in occurrence of TP and TF in all taxa, except the two (H. fomes and $X$. granatum), where up to a certain limit of substrate salinity, TP and TF amplified, further than which, it dropped down indicating their less ability to salt adaptability. The antioxidative response in plants is complex and scavenging of ROS takes place by interaction of enzymatic and nonenzymatic components. Jithesh et al. (2006) also pronounced that most salt tolerance studies have explored antioxidant status in leaves. This is not 
surprising considering the fact that salt stress aggravates ROS mainly in the chloroplast compartments of leaf cells. It has long been established that antioxidant ability of polyphenols and flavonoids is attributed to extent of free radical scavenging (Hatano et al., 1989). Present investigation confirmed that efficient free radical scavenging aptitude signify the efficacious existence of plant taxa in salt stress. The substrate salinity of Indian Sundarbans is presently much higher and imposing much inhospitality to some key species of this area for their sustainable existence (Haq et al., 1999; Nandy et al., 2007). Accumulation of elevated and positively correlated antioxidative enzymes and other compatible metabolite (low molecular proteins and amino acids) have demonstrated as combat force against salinity stress in B. gymnorrhiza, E. agallocha and $P$. paludosa along with some other predominant flora of this area, but $H$. fomes and $X$. granatum are lagging behind in these regards (Dasgupta et al., 2013). The present opinion on relative incidence of antioxidative secondary metabolites and ROS scavenging ability with respect to substrate salinity would be symptomatic towards the emaciated occurrence of $H$. fomes and $X$. granatum than those of the other three investigated taxa.

\section{ACKNOWLEDGMENT}

The authors are sincerely indebted to the Director, Sundarbans Biosphere Reserve and Chief Principal Conservator of Forest and Wildlife, Government of West Bengal, for providing required permission to conduct field work in the Sundarbans Reserved Forest time to time.

\section{REFERENCES}

AGATI, G., M. TATTINI. 2010. Multiple functional roles of flavonoids in photoprotection. New Phytol.186: 786-793.

AGATI, G., E. AZZARELLO, S. POLLASTRI, M. TATTINI. 2012. Flavonoids as antioxidants in plants: Location and functional significance. Plant Sci. 196: 67-76.

ALAM, E.A. 2011. Phytochemical screening on different plant parts of some succulent plants of Egypt. New York Sci.J. 4:15-18. 
Role of Secondary Metabolites and Radical Scavenging Aptitude

ALONGI, D.M. 2009. The Energetics of Mangrove Forests. Springer, Dordrecht, $216 \mathrm{p}$.

ARNAO, M.B. 2000. Some methodological problems in the determination of antioxidant activity using chromogen radicals: a practical case. Trends Food Sci. Technol. 11:419-421.

BANDARNAYAKE, W.M. 2002. Bioactivities, bioactive compounds and chemical constituents of mangrove plants. Wetl. Eco. Manag. 10: 421-452.

BANERJEE, D., S. CHAKRABORTY, A.K. HAZRA, S. BANERJEE, J. ROY, B. MUKHERJEE. 2008. Antioxidant activity and total phenolics of some mangroves in Sundarbans. Afr. J. Biotech. 7: 805-810.

BANERJEE, L.K. 1999. Mangroves of Orissa coast and their ecology. Bishen Singh Mohendra Pal Singh, Dehra Dun, India. pp 41.

BRUNETTI, C., M. DI FERDINANDO, A. FINI, S. POLlASTRI, M. TATTINI. 2013. Flavonoids as Antioxidants and Developmental Regulators: Relative Significance in Plants and Humans. Internatl. J. Mol. Sci. 14: 3540-3555.

CHANDINI, S.K., P. GANESAN, N. BHASKAR. 2008. In vitro antioxidant activities of three selected brown seaweeds of India. Food Chem. 107: 707713.

COTElle, N., J. L. BERNiER, J. P. CATTEAU, J. POMMERY, J. C. WALLET, E. M. GAYDOU. 1996. Antioxidant properties of hydroxyflavones. Free Rad. Biol. Med. 20: 35-43.

CUSHNIE, T.P.T., A. J. LAMB. 2005. Antimicrobial activity of flavonoids. Internatl. J. Antimicrob. Agents. 26: 343- 356.

DASGUPTA, N., P. NANDY, S. DAS. 2013. Salt Stress: A biochemical and physiological adaptation of some Indian halophytes of Sundarbans. In: Rout, G.R., A. B. Das (eds.) Molecular Stress Physiology of Plants, 155$177 \mathrm{p}$. Springer, India.

DASGUPTA, N., P. NANDY, C. SENGUPTA, S. DAS. 2012. Protein and enzymes regulations towards salt tolerance of some Indian mangroves in relation to adaptation. Trees: Struc. Func. 26: 377-391. 
DAVIES, K.J.A. 2000. Oxidative stress, antioxidant defenses and damage removal, repair and replacement systems. Internatil. Union of Biochem. Mol. Biolo. 50:279-289.

DIPLOCK, A.T. 1997. Will the 'good fairies' please prove to us that vitamin E lessens human degenerative of disease? Free Rad. Res. 27: 511-532.

DUAN, X.J., W. W. ZHANG, X. M. LI, B. G. WANG. 2006. Evaluation of antioxidant property of extract and fractions obtained from a red alga, Polysiphonia urceolata. Food Chem. 95: 27-43.

DUH, P.D., Y.Y. TU, G. C. YEN. 1999. Antioxidant activity of water extract of Harng Jyur (Chrysanthemum morifolium Ramat). Lebnesmittelwissenschaft and Technologie 32:269-277.

FOOD AND AGRICULTURAL ORGANIZATION, United Nations (FAO). 2007. The World's Mangroves 1980 - 2005. FAO Forestry Paper 153, FAO, Rome.

FELLER, I.C, D. F. WHIGHAM, J. P. O'NEILL, K. L. MCKEE. 1999. Effects of nutrient enrichment on within-stand cycling in a mangrove forest. Ecol. 80:2193-2205.

GIRI, C., E. OCHIENG, L. L. TIESZEN, Z. ZHU, A. SINGH, T. LOVELAND, J. MASEK, N. C. DUKE. 2011. Status and distribution of mangrove forests of the world using earth observation satellite data. Global Ecology. Biogeogr. 20: 154-159.

HALLIWELL, B., C. E. CROSS. 1994. Oxygen-derived species: their reaction to human disease and Environmental stress. Environ. Health Persp. 102(10): 5-12.

HAQ, S., Z. KARIM, M. ASADUZZAMAN, F. MAHTAB. 1999. Vulnerability and Adaptation to Climate Change for Bangladesh. Kluwer Academic Publishers, The Netherlands. ISBN-7923-5536-9.

HARO-VICENTE, J.F., C. MARTÍNEZ-GRACIÁ, G. ROS. 2006. Optimisation of in vitro measurement of available iron from different fortificants in citric fruit juices. Food Chem. 98: 639-648.

HASEGAWA, P. M., R. BRESSAN, J. M. PARDO. 2000a. The dawn of plant salt tolerant genetics. Trends Plant Sci. 5:317-319. 
Role of Secondary Metabolites and Radical Scavenging Aptitude

HASEGAWA, P.M., R. A. BRESSAN, J. K. ZHU, H. J. BOHNERT. 2000b. Plant cellular and molecular responses to high salinity. Ann. Rev. Plant Physiol. Plant Mol. Biol. 51: 463-499.

HATANO, T., R. EDAMATSU, M. HIRAMATSU, A. MORI, Y. FUJITA, T. YASUHARA, T. YOSHIDA. T. OKUDA. 1989. Effect of the interaction of tannins with co-existing substances. VI. Effect of tannins and related polyphenols on superoxide anion radical and on 1,1-diphenyl-2picrylhydrazyl radical. Chem. Pharma. Bull.37:2016-2021.

HERNES, P. J., R. BENNER, G. L. COWIE, M. A. GONI, B. A. BERGAMASCHI, J. I. HEDGES. 2001. Tannin diagenesis in mangrove leaves from a tropical estuary: A novel molecular approach. Geochimica et Cosmochimica Acta. 65:3109-3122.

HSU, S.Y., C. H. KAO. 2003. Differential effect of sorbitol and polyethylene glycol on antioxidant enzymes in rice leaves. Plant Growth Regul. 39: 8390 .

HUDA-FAUJAN, N., A. NORIHAM, A. S. NORRAKIAH, A. S. BABJI. 2009. Antioxidant activity of plants methanolic extracts containing phenolic compounds. Afr. J. Biotechnol. 8: 484-489.

IMLAY, J.A. 2003. Pathways of oxidative damage. Ann. Rev. Microb. 57: 395-408.

JIA, Z.S., M. C. TANG, J. M. WU. 1999. The determination of flavonoid contents in mulberry and their scavenging effects on superoxide radicals. Food Chem. 64: 555-559.

JITHESH, M.N., S. R. PRASHANTH, K. R. SIVAPRAKASH, A. K. PARIDA. 2006. Antioxidative response mechanisms in halophytes: their role in stress defence. J. Genet. 85:237-254.

KRISHNAMOORTHY, M., J. M. SASIKUMAR, R. SHAMNA, C. PANDIARAJAN, P. SOFIA, B. NAGARAJAN. 2011. Antioxidant activities of bark extract from mangroves, Bruguiera cylindrica (L.) Blume and Ceriops decandra Perr. Indian J. Pharma. 43: 557-562.

LEE, HUI-WEN., P. HAKIM, A. RABU, H. A. SANI. 2012. Antidiabetic effect of Gynura procumbens leaves extracts involve modulation of hepatic carbohydrate metabolism in streptozotocin-induced diabetic rats. $J$. Medicinal Plant Res. 6: 796-812. 
Dasgupta et al.

MCIVOR, A.L., T. SPENCER, I. MÖLLER, M. SPADLING. 2012. Storm Surge Reduction by Mangroves. Natural Coastal Protection Series: Report 2. Cambridge Coastal Research Unit Working Paper 41. p.36.

MEIR, S., J. KANNER, B. AKIRI, S. PHILOSOPH-HADAS. 1995. Determination and involvement of Aqueous Reducing Compounds in Oxidative Defence Systems of Various Senescing Leaves. J. Agric. Food Chem. 43: 1813-1819.

METCALFE, R.L. 1987. Plant volatiles as insect attractants. Crit. Rev. Plant Sci. 5: 251-301.

MIDDLETON, E. JR., C. KANDASWAMI. 1993. The Flavonoids. In: Harborne, J.B. (ed.) Advances in Research Since 1986, 619-652 p. Chapman and Hall, London.

M'RAHS, Z. OUERGHI, F. EYMERY, P. REY, M. HAJJI, C. GRIGNON, M. LACHAAL. 2007. Efficiency of Biochemical protection against toxic effects of accumulated salt differentiates Thellungiella halophila from Arabidopsis thaliana. J. Plant Physiol. 164:375-384.

NANDY, P., N. DASGUPTA, S. DAS. 2009. Differential expression of physiological and biochemical characters of some Indian mangroves towards salt tolerance. Physiol. Mol. Biol. Plants. 15: 151-160.

NANDY, P., S. DAS, M. GHOSE, R. SPOONER HART. 2007. Effects of salinity on photosynthesis, leaf anatomy, ion accumulation and photosynthetic nitrogen use efficiency in five Indian mangroves. Wetl. Ecol. Manag. 15:347-357.

NASKAR, K.R., D. N. GUHA BAKSHI. 1995. Vegetation pattern of the Sundarbans. Mangrove swamps of the Sundarbans - An ecological perspective. Naya Prakash, Calcutta, India.

NYCHAS, G. J. E., C. C. TASSOU, P. SKANDAMIS. 2003. Antimicrobials from herbs and spices. In: Roller, S.M. (ed.) Natural antimicrobials for the minimum processing of foods, 176-200 p. CRS Press, Woodhead Publishers, NY.

OSTROWSKAA, J., W. ŁUCZAJA, I. KASACKAB, A. RÓŻAŃSKIC, S. E. ELŻBIETA. 2004. Green tea protects against ethanol-induced lipid peroxidation in rat organs. Alcohol. 32: 25-32. 
Role of Secondary Metabolites and Radical Scavenging Aptitude

PARANI, M., M. LAKSHMI, B. ZEIGENHAGEN, M. FLADUNG, P. SENTHILKUMAR, A. PARIDA. 2000. Molecular phylogeny of mangroves VII. PCR-RFLP of trnS - pbsC and rbcL gene regions in 24 mangrove and mangrove associate species. Theor. Appl. Genet. 100: 454460.

PIETTA, P. G. 2000. Flavonoids as antioxidants. J. Nat. Prod. 63: 1035-1042.

POLLASTRI, S., M. TATTINI. 2011. Flavonols: Old compound for old roles. Annal. Bot. 108: 1225-1233.

RAHIM, A. A., E. ROCCA, J. STEINMETZ, K. M. JAIN, M. SANI IBRAHIM, H. OSMAN. 2008. Antioxidant activities of mangrove Rhizophora apiculata bark extracts. Food Chem. 107: 200-207.

RAVIKUMAR, S., M. GNANADESIGAN, P. SUGANTHI, A. RAMALAKSHMI. 2010. Antibacterial potential of chosen mangrove plants against isolated urinary tract infectious bacterial pathogens. Int. J. Med. Med. Sci. 2: 94-99.

RAVIKUMAR, S., G. RAMANATHAN, S. J. INBANESON, A. RAMU. 2011. Antiplasmodial activity of two marine polyherbal preparations from Chaetomorpha antennina and Aegiceras corniculatum against Plasmodium falciparum. Parasitol. Res. 108: 107-113.

RE, R. N., A. PELlEGRINI, A. PROTEGGENTE, M. PANNALA, C. YANG, R. EVANS. 1999. Antioxidant activity applying an improved ABTS radical cation decalorization assay. Free Rad. Biol. Med. 26: 1231-1237.

RIBEIRO, A.B., D. H. S. SILVA, V DA SILVA BOLZANI. 2002. Antioxidant flavonol glycosides from Nectandra grandiflora (Lauraceae). Eclet. Quim. Versa Oimpressa: 27 (special) Sao Paulo. (ISSN 0100-4670).

SHAHIDI, F. 2000. Antioxidants in food and food antioxidants. Food / Nahrung 44: 158-163.

SINGLETON, V. L., A. ROSSI. 1965. Colorimetry of Total Phenolics with Phosphomolybdic Phosphotungstic Acid Reagents. Am. J. Enol. Viticult. 16: $144-158$.

TIWARI, A. K. 2001. Imbalance in antioxidant defense and human diseases: Multiple approach of natural antioxidant therapy. Curr. Sci. 8: 1179-1187. 
UPADHYAY, V. P., RAJIV RANJAN, J. S. SINGH. 2002. The Human Mangrove Conflicts - The way out. Curr. Sci. 83: 1328-1336.

VADLAPUDI, V., K. C. NAIDU. 2009. Evaluation of Antioxidant potential of selected Mangrove Plants. J. Pharma. Res. 2: 1742-1745.

YILDIRIM, A., A. MAVI, A. KARA. 2001. Determination of antioxidant and antimicrobial activities of Rumex crispus L. extracts. J. Agric. Food Chem. 49: 4083-4089.

YONGXIN, LI., YU. SHANJIANG, L. DONG, P. PETER, W. LIN. 2012. Inhibitory effects of polyphenols toward HCV from the mangrove plant Excoecaria agallocha L. Bioorg. Med. Chem. Let. 22:1099-1102.

ZHANG, L.L., Y. M. LIN, H. C. ZHOU, S. D. WEI, J. H. CHEN. 2010. Condensed tannins from mangrove species Kandelia candel and Rhizophora mangle and their antioxidant activity. Molecules. 15: $420-431$.

ZURINA, H., M. F. YAM, A. MARIAM, P. AHMAD, M. Y. PAUZI. 2010. Antidiabetic properties and mechanism of action of Gynura procumbens water extract in streptozotocin-induced diabetic rats. Molecules, 15: 90089023. 